\title{
Assessment of English language Students' Preferences of the Methods of Teaching English in a Private Jordanian University
}

\author{
Dr. Mohammad A. Qasaimeh \\ Jordanian Ministry of Education \\ Tel: 962-77-215-5238_E-mail: mohd667@yahoo.com
}

\author{
Al-Mothana M. Gasaymeh (Corresponding author) \\ Department of Curriculum and Teaching \\ Al-Hussein Bin Talal University P.O. Box (20), Ma'an, Jordan \\ Tel: 962-78-164-6155 E-mail: gasaymeh@gmail.com
}

Received: November 5, 2015 Accepted: Dec.17, 2015 Published: February 1, 2016

doi:10.5296/jse.v6i1.8779 URL: http://dx.doi.org/10.5296/jse.v6i1.8779

\begin{abstract}
For effective language learning and teaching, both learners' skills and assumptions should gain enough interest from their teachers. For the sake of that idea, students should have the opportunity to express their preferences regarding the ways of teaching and learning English language. Having in mind the idea that learners' preferences of the ways of teaching English language are vital importance their learning, we asked students at an English language department in a Jordanian private university to state their views on how they prefer to learn English. As a further step, teachers working at the same department with the same students were also asked to express their views regarding the extent of their awareness of their students' learning preferences. The data obtained uncovered significant results suggesting a need for a closer cooperation and collaboration among students and their teachers concerning how English language learning activities should be re-arranged and implemented in the classroom.
\end{abstract}

Keywords: English language, Teaching methods, Students' preferences. 


\section{Introduction}

In Jordan, sometimes English language teachers face students' resistance or unwillingness when they tend to introduce a new instructional activity in the classroom. Some students want more opportunities to participate in free conversation, expressing their wishes towards a more communicatively and collaboratively oriented approach. On the other hand, there are those who would prefer more paper-based materials and individuality in learning English. We believe that the teacher, while implementing a type of activities in a language classroom, should take into consideration such learners' varieties of preferences.

In this respect as Corder (1977) claimed that for, successful language "teaching-learning process is going to be dependent upon the willing co-operation of the participants (teachers and students) in the interaction and an agreement between them upon the goals of their interaction. Co-operation cannot be imposed but must be negotiated "(p. 13), as you can take

We would like to make use of the last sentence in the quotation above: "Co-operation cannot be imposed but must be negotiated." If we truly believe that implementing preferences felt by the learner himself is of special importance for effectiveness of language learning, then a specific kind of negotiation is wanted between the participants (teachers and students). Information about expected roles and claimed expectations has to be exchanged, both teachers' and learners' understanding of each others' needs and preferences have to be a center point in the process of education. Zhang (2010) pointed to the importance of cooperative language learning that show the importance of the interaction and communication among students and between students and teachers, and the role of teacher as facilitator.

Although many teachers acknowledge and admit the need to understand the individual differences in terms of needs and preferences, some of them do not consult learners in conducting language activities. For instance, the basis for students' unwillingness to cooperate in English language learning may be due to the idea that learners are not capable enough to express their needs to learn and how they want to learn.

We should agree that such a negotiation between students and their teachers would enforce a change in the traditional roles of the teacher and students. That is especially true in Jordan, where a majority of learners and teachers wish to continue to play the role of "pupil-acquirer of knowledge" and "teacher-transmitter of knowledge". Such a process of change requires sharing information about each other's perceptions of classroom aims and events, and an agreement on actual and practical needs and preferences, putting in consideration that the teacher is no longer a streaming source of information especially after the recent revolution in the world of telecommunication which makes the world as a global village. Abidin, Rezaee, Abdullah, \& Singh (2011) found significant relationship between overall academic achievement and learning styles. Willing (1987) assessed the learning styles of 517 adult ESL learners in Australia. Based on their responses to a 30-item questionnaire, Willing aimed at identifying how differences in cognitive learning styles affected learners' preferences in six different areas: 


\section{Macrothink}

1. preferences for specific kinds of classroom activities;

2. preferences for special types of teacher behavior;

3. preferences for particular grouping arrangements;

4. preferences for some aspects of language which need a kind of emphasis;

5. preferences for some sensory modes, such as visual, auditory, or tactile learning; and

6. Preferences for particular modes of learning on one's own outside class.

It was found that differences in cognitive styles do affect learners' preferences for some learning styles. For example, concrete learners tended to choose the following:

- In class, I like to learn by games.

- I like to learn English by working in pairs.

Analytical learning styles, however, preferred the following:

- I like to study grammar.

- I like the teacher to let me find my mistakes.

In another assessment, learners' preferences have been much emphasized in some research papers. Reid (1987), for example, based on survey data, distinguished four learning styles:

1. visual learning (for example, reading and studying charts);

2. auditory learning (for example, listening to lectures or audio tapes);

3. kinesthetic learning (involving physical responses); and

4. Tactile learning (hands-on learning, as in building models).

Reid (1987) developed a questionnaire to students coming from varying language backgrounds to assess their preferences. This study clarified that the learners' preferences often differ from those of native speakers of American English. It cleared a general preference for kinesthetic and tactile learning styles. Yeh \& Wang, (2013) categorized perceptual learning styles in relation to vocabulary learning to auditory, visual-verbal (with text), visual-nonverbal (with pictures), and mixed preferences

Despite the above mentioned, Richards and Lockhart (1994) argued that such information in relation to students' preferences of learning English can prove to be significant, but the idea of putting "learners into boxes labeled according to cognitive styles" is unacceptable (p. 62-63). Nunan (1989) points out that considering learners' preferences is crucial in establishing a learner-centered curriculum. Such importance given to students' preferences has also been emphasized in Barkhuizen's (1998) study, in which he reported an assessment of high school ESL learners' perceptions of the language teaching-learning activities presented in their classes. The outcome of such investigation surprised the teachers in that perceptions of teachers and students differed greatly from each other. Block, $(1994,1996)$ 
stated that synergy between students' and teachers' aims regarding task assignment and performance must be stressed. The same idea was stated by Sternberg (1995) while discussing styles of thinking that are the foundation from which styles of learning do emerge.

Bada, and Okan (1993) conducted a study to elicit Turkish students' language learning preferences. Depending on the results of their study, they highly emphasized the willing co-operation of the participants (students \& teachers) in the interaction and the agreement between them upon the goals of their interaction as co-operation cannot be imposed but must be negotiated.

Felder, \& Soloman, (2000) categorized learners in their article "learning styles and strategies" as, active versus reflective learners, sensing versus intuitive learners, visual versus verbal learners, sequential versus global learners, giving each classification its own qualities, distinctive features and their preferences.

As response to these studies and hoping to add a fruitful contribution in the same field, this study is conducted.

\section{Methodology}

\subsection{Problem of the study}

Based on the researchers' experiences in education, they notices that the parents usually ask, why are our kids weak in English language._Teachers usually ask, why are our students unable to understand English language instructions, ideas and rules? The researchers have the feeling that there is a instructional gap between teachers and their students and that gap was the reason behind such complains.

\subsection{Purpose of the study}

The study aims at investigating learners' preferences of the ways of teaching English language and teachers views regarding the extent of their awareness of their students' learning preferences.

\subsection{Questions of the study}

1- Are teachers aware of their learners' needs, capabilities, potentials, and preferences in relation to English language instructions?

2- Is there a correlation between most students' tendencies and their teachers' belief within in class activities?

\subsection{Participants}

The subjects who participated in this research were 159 English language students ( 80 female; 79 male) and 23 instructors (6 female; 17 male) teaching English at the English language Department in a Jordanian private university. The students' age ranged between 19-34 years; teachers' age ranged between 28 and 60 years. 


\subsection{Instruments}

The data for this study are collected through a 13-item questionnaire, adapted from Brindley (1984). The questionnaire has two versions; Version one that was designed for students and Version two that was designed for teachers. Apart from addressing and reference conventions, the versions do not differ significantly.

Each item in the questionnaire assesses a particular second language topic. However, they can be categorized into three major classes: Learning, error correction, and assessment and/or evaluation. The learning class is divided into two subcategories: Course content, and non-course content. While course content includes strategies for learning through the basic four skills, learning and expanding vocabulary, making use of audio-visual aids, and general second language improvement. The Non-content subcategory looks to individual preferences in actualizing the course content subcategory. Here we ask whether students benefit from working in groups, pairs, or individually, and if/how they specify and utilize time for homework, inside and/or outside classroom. Error Correction include peer correction, while assessment and/or evaluation include preference for homework, time allocation for homework, assessment of language performance, and expression of satisfaction in progress.

\subsection{Data Analysis}

The data collected were analyzed using the percentages to achieve the main goal of the study. Results concerning each item in the questionnaire were presented in a separate table

\section{Results and Discussion}

Presented here are the results for each item, beginning with item 1. In the students' version, we asked students if they were satisfied with their overall achievement in English, and in the teachers' version, whether they were pleased with their students' achievement in English.

Table 1. Satisfaction with Achievement

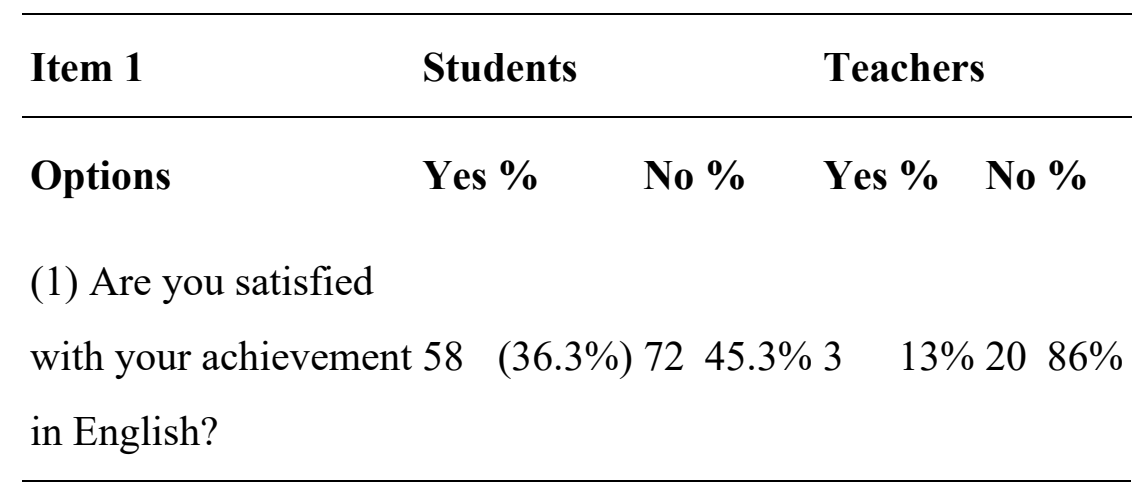

As shown in Table 1, about half of the students replied negatively regarding their satisfaction with their achievement in English language courses. However, the instructors were more unhappy with students' achievements in English, where 86\% of the instructors replied negatively regarding their satisfaction with their students' achievement in English language courses.. Thus, both students and teachers are aware of students' dissatisfaction with their 
achievement in English. Such findings support the argument that there are needs to examine students' preferences of learning English language and the actual practice.

With item2, being one of the non-course content items, students were asked to express whether they prefer working individually, or in any other way, and whether their instructors were in fact aware of that. Results for this item are presented in the table below:

Table 2. Working Styles

\begin{tabular}{llllllllll}
\hline Item 2 & \multicolumn{1}{l}{ Students } & \multicolumn{1}{l}{ Teachers } \\
\hline Options & Yes & $\%$ & No & $\%$ & Yes & $\%$ & No & $\%$ \\
(1) individually & 69 & $43.3 \%$ & 74 & $46.5 \%$ & 11 & $47.8 \%$ & 12 & $52 \%$ \\
(2) in pairs & 68 & $42.8 \%$ & 59 & $37.1 \%$ & 9 & $39 \%$ & 14 & $60 \%$ \\
(3) in small groups & 83 & $52.2 \%$ & 49 & $30.8 \%$ & 8 & $35 \%$ & 15 & $63 \%$ \\
(4) in one large group & 43 & $27 \%$ & 81 & $50.9 \%$ & 19 & $83 \%$ & 4 & $17 \%$ \\
(5) other & & & & 1 & $.06 \%$ & & & & \\
\hline
\end{tabular}

The results for this item suggest that students are generally willing to work either in small groups, $52.2 \%$, or in pairs, $42.8 \%$ and individually, $43.3 \%$. Teachers believe that students prefer working in one large group, $83 \%$ and $47.8 \% \%$ individually while the belief in teaching in pairs and in small groups doesn't score more than $39 \%$. This correlation indicates teachers' unawareness of students' preference regarding in-class learning. It is obvious that students do not like working in large groups, and their teachers aren't aware of that. This is a clear message to the teacher that students feel more comfortable, productive and relaxed by working individually or in pairs, where their voices would be heard, and views listened to and valued.

For item3, learners seem to be divided on the issue of homework. With item 3, we asked learners if they wanted work assigned as an outside classroom activity. The results can be observed in the table below: 
Table 3. Preference for Homework

\begin{tabular}{|c|c|c|}
\hline Item 3 & Student & \\
\hline Options & Yes \% & No $\%$ \\
\hline
\end{tabular}

As can be seen, only $18.2 \%$ of the learners believe that some sort of homework activity wouldn't be helpful to their learning, while $63.3 \%$ did not hold this belief.

With item4, we tried to see how students would like to utilize the time they allocate for homework. Their options are (1) preparing for the next class, (2) reviewing the day's work, and (3) other. The results received for this item are illustrated in the table below:

Table 4. Time Allocation for Homework

\begin{tabular}{llllll}
\hline Item 4 & \multicolumn{3}{c}{ Students } \\
\hline Options & Yes \% & No \% \\
(1) preparing for the next class & 78 & $49.1 \%$ & 38 & $23.9 \%$ \\
(2) reviewing the day's work & 98 & $61.6 \%$ & 18 & $11.3 \%$ \\
(3) other & & & & \\
\hline
\end{tabular}

Forty nine percent of the students give priority to Option (1) that is, preparing for the next class session. $61.6 \%$ would like to utilize this time reviewing the day's work. Learners may usually be inclined to finish a task in the classroom, and spend their outside-classroom time working on new topics. Assignments concerning future topics, with new insights and views added seem to appeal more to students. 
Table 5. Learning Inside/Outside Classroom

\begin{tabular}{llllllll}
\hline Item 5 & \multicolumn{1}{c}{ Students } & \multicolumn{5}{c}{ Teachers } \\
\hline Options & Yes $\%$ & No & $\%$ & Yes $\%$ & No $\%$
\end{tabular}

(1) spend all your learning time in the 40 $25.2 \%$ 113 $71.1 \%$

4 $17 \%$ $19 \quad 82 \%$ classroom

(2) spend some time in the classroom and some time 143 $89.9 \%$ 13 practicing your English with people outside

(3) other

About $90 \%$ of students expressed their negative attitude towards a non-classroom-centered learning. The results received by teachers display a significant correlation with those of students, $82 \%$.

With item 6, we asked whether students like learning by (1) listening, (2) reading, (3) repeating what they hear, (4) listening and taking notes, (5) copying from the board, and (6) making summaries. The results for this item are presented in the table below: 
Table 6. Ways of Learning

\begin{tabular}{|c|c|c|c|c|c|c|c|c|}
\hline \multirow{2}{*}{$\begin{array}{l}\text { Item } 6 \\
\text { Options }\end{array}$} & \multicolumn{4}{|c|}{ Students } & \multicolumn{4}{|c|}{ Teachers } \\
\hline & Yes & $\%$ & No & $\%$ & Yes & $\%$ & No & $\%$ \\
\hline (1) listening & 103 & $67.3 \%$ & 50 & 31.4 & 19 & $82 \%$ & 4 & $17 \%$ \\
\hline (2) reading & 96 & $60.4 \%$ & 43 & $27 \%$ & 9 & $39 \%$ & 14 & $61 \%$ \\
\hline (3) copying from the board & 64 & $40.3 \%$ & 78 & $49.1 \%$ & 17 & $73 \%$ & 6 & $26 \%$ \\
\hline (4) listening and taking notes & 132 & $83 \%$ & 19 & $11.9 \%$ & 20 & $87 \%$ & 3 & $13 \%$ \\
\hline (5) reading and making notes & 89 & $56 \%$ & 53 & $33.3 \%$ & 9 & $39 \%$ & 14 & $61 \%$ \\
\hline (6) repeating what you hear & 103 & $64.8 \%$ & 42 & $26.4 \%$ & 3 & $13 \%$ & 20 & $87 \%$ \\
\hline (7) making summaries & 111 & $69.8 \%$ & 24 & 15.1 & 7 & $30 \%$ & 16 & $69 \%$ \\
\hline (8) other & & & & & & & & \\
\hline
\end{tabular}

Eighty three percent of students preferred learning by listening and taking notes and $69.8 \%$ of students prefer making summaries. The result shows that learners do not want to adopt a totally passive role in the learning process, since they could have otherwise focused on the first two options, "listening" or "reading". Low percentages received for "copying from the board" (40.3\%). Making summaries was preferred by $69.8 \%$ of students. Teachers' responses to this were only $30 \%$, however. One-directional instruction, i.e., from teacher to student is not the preferred mode for students.

Vocabulary learning is a complicated task, though many may perceive it as simple. The learner has to perform several tasks when learning a new word: spelling, pronunciation, stress, grammatical class, semantic category, in combination with other semantic and grammatical elements in the sentence, and possible contextual occurrence in various situations. Thus, a language learner, attempting to learn a word, may overlook these characteristics of the word, and remain content with one or two. With item 7, we wanted to find out as to how learners would like to learn new vocabulary. The options are: "by using the word in a sentence," "thinking of relationship between known and new," "saying or writing the word several times," "guessing the unknown," and "reading with no dictionary help." Results received for this item can be observed below: 
Table 7. Vocabulary Learning 2016, Vol. 6, No. 1

\begin{tabular}{|c|c|c|c|c|c|c|c|c|}
\hline \multirow{2}{*}{$\begin{array}{l}\text { Item } 7 \\
\text { Options }\end{array}$} & \multicolumn{3}{|c|}{ Students } & \multicolumn{5}{|c|}{ Teachers } \\
\hline & Yes & $\%$ & No & $\%$ & Yes & $\%$ & No & $\%$ \\
\hline (1) using new words in a sentence & 132 & $83 \%$ & 15 & $9.4 \%$ & 7 & $30 \%$ & 16 & $70 \%$ \\
\hline $\begin{array}{l}\text { (2) thinking of relationships } \\
\text { between known and new }\end{array}$ & 111 & $69.8 \%$ & 37 & $23.3 \%$ & 08 & $35 \%$ & 15 & $65 \%$ \\
\hline $\begin{array}{l}\text { (3) saying or writing words several } \\
\text { times }\end{array}$ & 90 & $56.5 \%$ & 51 & $32.1 \%$ & 03 & $13 \%$ & 20 & $87 \%$ \\
\hline (4) avoiding verbatim translation & 73 & 45.9 & 57 & $35.8 \%$ & 05 & $23 \%$ & 18 & $78 \%$ \\
\hline (5) guessing the unknown & 77 & 48.4 & 67 & $42.1 \%$ & 011 & $48 \%$ & 12 & $52 \%$ \\
\hline $\begin{array}{l}\text { (6) reading without looking up } \\
\text { words }\end{array}$ & 47 & $29.6 \%$ & 83 & $52.2 \%$ & 015 & $65 \%$ & 8 & $35 \%$ \\
\hline (7)other & & & 2 & $1.3 \%$ & & & & \\
\hline
\end{tabular}

Establishing a semantic relation with other words received the percentage, $69.8 \%$ but the highest percentage is gained by using new words in a sentence and the percentage is $83 \%$. Teachers' responses for this option, 30\%, show low correlation to those of students'.

"Guessing the unknown" is another option which received relatively high percentages from students $(84.4 \%)$, but not the teachers $(48 \%)$. Thus, a plausible explanation might be that teachers don't motivate students to infer meaning from context but they heavily rely on dictionary use.

As in any other field, errors in language teaching, learning, perception and production are inescapable. What is important though is coping with them in such a way that they do not frustrate, inhibit and/or discourage language learners. With item 8, we asked learners as to how they would prefer to be corrected by their instructors. Results concerning this item are cited in the table below: 
Table 8. Error Correction

\begin{tabular}{|c|c|c|c|c|c|c|c|c|}
\hline \multirow{2}{*}{$\begin{array}{l}\text { Item } 8 \\
\text { Options }\end{array}$} & \multicolumn{4}{|c|}{ Students } & \multicolumn{4}{|c|}{ Teachers } \\
\hline & Yes & $\%$ & No & $\%$ & Yes & $\%$ & No & $\%$ \\
\hline (1) immediately, in front of everyone & 73 & 45.9 & $\% 72$ & $45.3^{\circ}$ & 109 & $39 \%$ & 614 & $61 \%$ \\
\hline $\begin{array}{l}\text { (2) later, at the end of the activity, in } \\
\text { front of everyone }\end{array}$ & 85 & 53.5 & $\% 51$ & $32.1^{\circ}$ & 012 & $52 \%$ & 011 & $48 \%$ \\
\hline (3) later, in private & 94 & 59.1 & $\% 42$ & $26.4^{\circ}$ & o 19 & $83 \%$ & 64 & $17 \%$ \\
\hline (4) other & 4 & $2.5 \%$ & & & & & & \\
\hline
\end{tabular}

As is shown, $59.1 \%$ of students would like to be corrected by their instructors in private. And teachers, by $83 \%$, are aware of this preference. However, $45.9 \%$ of students do not mind having their instructors correct them publicly. Our belief is that error correction, made immediately, or later, does not have much impact on learners' second language competence and performance as do manner, approach and attitude of the teacher during the error correction process. To reiterate, the approach of the teacher is of crucial value here.

Item 9 is also related to error correction. Here, students were asked whether (1) they would mind if corrected by other students, or (2) asked to correct themselves. In the table below, we cite the results about this item:

Table 9. Peer Correction

\begin{tabular}{|c|c|c|c|c|c|c|c|c|}
\hline \multirow{2}{*}{$\begin{array}{l}\text { Item } 9 \\
\text { Options }\end{array}$} & \multicolumn{4}{|c|}{ Students } & \multicolumn{4}{|c|}{ Teachers } \\
\hline & Ye & $\%$ & No & $\%$ & Ye & $\%$ & No & $\%$ \\
\hline $\begin{array}{l}\text { (1) do you mind if other students sometimes } \\
\text { correct your written work }\end{array}$ & 52 & 32. & 1095 & $59.7 \%$ & 65 & $22^{\circ}$ & 018 & $78 \%$ \\
\hline $\begin{array}{l}\text { (2) do you mind if the teacher sometimes } \\
\text { asks you to correct your work }\end{array}$ & 92 & 57. & 1062 & $39 \%$ & 16 & $69^{\circ}$ & 07 & $31 \%$ \\
\hline
\end{tabular}

As can be observed here, a significant number of students would mind having their written work corrected by other students $(59.7 \%)$. Teachers also, by $78 \%$, render a co-relational percentage here. Regarding correcting their own work, students, by $57.9 \%$, indicated that they would gladly correct themselves with no external intervention, and teachers, by a rather high percentage (69\%), shared this view with their students. 
With item10, we asked learners whether they like learning from (1) television/video/films, (2) radio, (3) tapes/cassettes, (4) written material, (5) the blackboard, or (6) pictures/posters. The results received for this item are given in the table below:

Table 10. Media Preference

\begin{tabular}{llllllllll}
\hline Item 10 & \multicolumn{2}{l}{ Students } & \multicolumn{5}{c}{ Teachers } \\
\hline Options & Yes & $\%$ & No & $\%$ & Yes $\%$ & No $\%$ \\
(1) television/video/films & 119 & $74.8 \%$ & 28 & $17.6 \%$ & 21 & $91 \%$ & 2 & $9 \%$ \\
(2) radio & 71 & $44.7 \%$ & 70 & $44 \%$ & 13 & $57 \%$ & 10 & $43 \%$ \\
(3) tapes/cassettes & 95 & $59.7 \%$ & 46 & $28.9 \%$ & 14 & $60 \%$ & 9 & $40 \%$ \\
(4) written material & 118 & $74.2 \%$ & 32 & $20.1 \%$ & 8 & $35 \%$ & 15 & $65 \%$ \\
(5) the blackboard & 103 & $64.8 \%$ & 31 & $19.5 \%$ & 20 & $87 \%$ & 3 & $13 \%$ \\
(6) pictures/posters & 104 & $65.4 \%$ & 31 & $19.5 \%$ & 7 & $30 \%$ & 16 & $70 \%$ \\
(7) other & 1 & $.06 \%$ & & & & & & & \\
\hline
\end{tabular}

Television and video, being powerful media, receive a high percentage of preference $(74.8 \%$ from students, and 91\% from teachers). We can observe that Option 4, "learning from written material", also received relatively similar percentage of learners' preference: $74.2 \%$ from students', but except 35\% from teachers'.

Item 11 delves into what learners find very useful in the classroom: (1) role play (2) language games, (3) songs, (4) talking with and listening to other students, (5) memorizing conversations/dialogues, (6) getting information from guest speakers, (7) getting information from planned visits, (8) writing a learning diary, and (9) learning about culture. Pertaining results are illustrated in the table below: 
Table 11. Learning Activities

\begin{tabular}{|c|c|c|c|c|c|c|c|c|}
\hline \multirow{2}{*}{$\begin{array}{l}\text { Item } 11 \\
\text { Options }\end{array}$} & \multicolumn{4}{|c|}{ Students } & \multicolumn{4}{|c|}{ Teachers } \\
\hline & Yes & $\%$ & No & $\%$ & Yes & $\%$ & No & $\%$ \\
\hline (1) role play & 55 & $35 \%$ & 98 & $62 \%$ & 6 & $26 \%$ & 17 & $74 \%$ \\
\hline (2) language games & 89 & $56 \%$ & 62 & $39 \%$ & 5 & $22 \%$ & 18 & $78 \%$ \\
\hline (3) songs & 71 & $45 \%$ & 74 & $47 \%$ & 4 & $17 \%$ & 19 & $83 \%$ \\
\hline $\begin{array}{l}\text { (4) talking with and } \\
\text { listening to other } \\
\text { students }\end{array}$ & 129 & $81 \%$ & 27 & $17 \%$ & 19 & $82 \%$ & 4 & $18 \%$ \\
\hline $\begin{array}{l}\text { (5) memorizing } \\
\text { conversations/dialogues }\end{array}$ & 96 & $60 \%$ & 60 & $38 \%$ & 15 & $69 \%$ & 8 & $31 \%$ \\
\hline $\begin{array}{l}\text { (6) getting information } \\
\text { from guest speakers; }\end{array}$ & 80 & $50 \%$ & 72 & $45 \%$ & 9 & $39 \%$ & 14 & $61 \%$ \\
\hline $\begin{array}{l}\text { (7) getting information } \\
\text { from planned visits }\end{array}$ & 87 & $54 \%$ & 60 & $38 \%$ & 10 & $43 \%$ & 13 & $57 \%$ \\
\hline $\begin{array}{l}\text { (8) writing a learning } \\
\text { diary }\end{array}$ & 106 & $67 \%$ & 47 & $30 \%$ & 8 & $35 \%$ & 15 & $65 \%$ \\
\hline $\begin{array}{l}\text { (9) learning about } \\
\text { culture }\end{array}$ & 118 & $74 \%$ & 36 & $23 \%$ & 18 & $78 \%$ & 5 & $22 \%$ \\
\hline
\end{tabular}

The striking point about these results is that students believe that student-to-student interaction is most beneficial among the options cited here. Students express this belief by $81.1 \%$. Teachers, by $82 \%$, are aware of such a preference, and provide situations which lead to student-student activities. "Learning about culture" also received high percentages from both students and teachers (74.2\% and $78 \%$ respectively).

With item12, we asked about assessments: how would learners like to develop an idea about their language competence and performance. Their choices were: (1) through written tasks set by the teacher, or (2) ability to use the language they have learnt in real-life situations. Results are presented in the table below: 
Table 12. Assessment of Language Performance

\begin{tabular}{|c|c|c|c|c|c|c|}
\hline \multirow{2}{*}{$\begin{array}{l}\text { Item } 12 \\
\text { Options }\end{array}$} & \multicolumn{2}{|l|}{ Students } & \multicolumn{4}{|c|}{ Teachers } \\
\hline & Yes \% & No $\%$ & Yes & $\%$ & No & $\%$ \\
\hline (1) written tasks set by the teacher & $12075.5 \% 3$ & $3421.4 \%$ & 11 & $47 \%$ & 12 & $53 \%$ \\
\hline $\begin{array}{l}\text { (2) using the language you have learnt } \\
\text { in real-life situations }\end{array}$ & $13786.2 \% 1 \xi$ & $1811.3 \%$ & 20 & $87 \%$ & 3 & $13 \%$ \\
\hline (3) other & & & & & & \\
\hline
\end{tabular}

An overwhelming majority $(86.2 \%)$ stated that they are capable of telling whether they are doing well or badly in authentic communications and a significant number of teachers $87 \%$ believe that their students usually assess themselves based on their second language performance in such situations.

Teachers can and should indeed occasionally refer to students' opinion about their performance, and ask for recommendations in order to create better learning situations. Such "non-grading" reference to students' views may yield some outstanding results guiding teachers in many ways, such as : material development, presentation, teacher-student interaction, etc.

The satisfaction learners get from their second language performance varies from student to student. Some are after high marks; some after command of second language; and some after both. With item13, we asked learners if they get a sense of satisfaction from (1) having their work graded, (2) being told that they have made progress or (3) feeling more confident in situations which they found difficult before. The results received are given in the table below: 
Table 13. Expression of Satisfaction in Progress

\begin{tabular}{|c|c|c|c|c|c|c|}
\hline \multirow{2}{*}{$\begin{array}{l}\text { Item } 13 \\
\text { Options }\end{array}$} & \multicolumn{2}{|l|}{ Students } & \multicolumn{4}{|c|}{ Teachers } \\
\hline & Yes \% & No $\%$ & Yes & $\%$ & No & $\%$ \\
\hline (1) having your work graded; & $12276.7 \%$ & $3320.8 \%$ & 19 & $83 \%$ & 4 & $17 \%$ \\
\hline $\begin{array}{l}\text { (2) being told that you have made } \\
\text { progress }\end{array}$ & $11874.2 \%$ & $3723.3 \%$ & 18 & $78 \%$ & 5 & $22 \%$ \\
\hline $\begin{array}{l}\text { (3) feeling more confident in } \\
\text { situations that you found difficult } \\
\text { before }\end{array}$ & $12679.2 \%$ & 2717.6 & 9 & $39 \%$ & 14 & $61 \%$ \\
\hline (4) other & & & & & & \\
\hline
\end{tabular}

Students, at $79.2 \%$, feel satisfied in seeing themselves performing confidently in situations where they would feel less confident before. Thus, high grades fall short in giving learners genuine satisfaction. Teachers $83 \%$, share this view with their students. However, by $78 \%$, the same teachers feel that learners would like to be told they have made good progress. However, students' responses to this particular option (74.2\%) are far lower than the teachers.

- Students' tendency toward working individually, in pairs and/or in small groups isn't well perceived by teachers.

- A significant number of students expressed their views in favor of more outside-classroom activities that would help them gain proficiency in English; teachers' responses seem to have well correlation with these views.

- Types of learning that focus merely on receptive skills do not appeal to students; there is a significant tendency among learners towards class content that observes both receptive and productive skills emphasized equally.

- Vocabulary learning for students is not a writing activity. The most significant way of mastering new words is in fact 'thinking of relationships between known and new' and 'guessing the unknown from context' which comes after using the new words in sentences and such tendency is not well perceived by teachers.

- Being corrected by either the teacher or other students does not seem to bother students that much.

- In classroom sessions, students would like to see more instructive television programs shown to them, rather than extensive use of chalk board or tape recorders, and this isn't well perceived by the teachers too. 
- Students expressed views that they would feel better satisfied with their language proficiency level when they see themselves involved and actively functioning in English. External judgment regarding their English lnaguage competence and performance does not seem to be that realistic and appealing to them as it has the least score. Such tendencies have very low correlation with teachers' belief about their students.

- To conclude, there is very low correlation seems to appear between most students' tendencies and their teachers' belief in most of the items which implies poor teachers' awareness of their students' learning preferences, needs, capabilities, and potentials.

Effective language teaching and learning can only be achieved when teachers are aware of their learners' needs, capabilities, potentials, and preferences in meeting these needs. In this study, we have only dealt with the preferences. Here, we have observed that students' preferences don't correlate with those of teachers' in many instances. The results obtained here call for a step forward towards a teacher-student co-operation in designing syllabuses, doing weekly course planning, and classroom management.

\section{Conclusions}

The findings obtained from this research provide some significant value, suggesting that:

\section{References}

Abidin, M. J. Z., Rezaee, A. A., Abdullah, H. N., \& Singh, K. K. B. (2011). Learning styles and overall academic achievement in a specific educational system. International Journal of Humanities and Social Science, 1(10), 143-152.

Bada, E., \& Okan, Z. (1993). Students' language learning preferences.TESL.EJ.Vol.4.No3.May 2000. http://www.tesl-ej.org/wordpress/issues/volume4/ej15/ej15a1/

Barkhuizen, G.P. (1998). Discovering learners' perceptions of ESL classroom teaching/learning activities in a South African context. TESOL Quarterly, 32, 85-108. http://dx.doi.org/10.2307/3587903

Block, D. (1994). A day in the life of a class: Teacher/learner perceptions of task purpose in conflict. System, 22, 473-486. http://dx.doi.org/10.1016/0346-251X(94)90004-3

Block, D. (1996). A window on the classroom: Classroom events viewed from different angles. In K.M. Bailey and D. Nunan (Eds.), Voices from the Language Classroom: Qualitative Research in Second Language Education. Cambridge: Cambridge University Press.

Brindley, G. (1984). Needs Analysis and Objective Setting in the Adult Migrant Education Program. Sydney: NSW Adult Migrant Education Service.

Brindley, G. (1989). The role of needs analysis in adult ESL programme design. In R.K.Johnson (Ed.), The Second Language Curriculum. Cambridge: Cambridge University Press. http://dx.doi.org/10.1017/CBO9781139524520.007 


\section{Macrothink}

Journal of Studies in Education

ISSN 2162-6952

2016, Vol. 6, No. 1

Corder, S.P. (1977). Language teaching and learning: a social encounter. In Brown, Yorio, and Crymes (Eds.), On TESOL'77. Washington,D.C.: TESOL.

Felder, R. M., \& Soloman, B. A. (2000). Learning styles and strategies. At URL: http://www. engr. ncsu. edu/learningstyles/ilsweb. html.

Nunan, D. (1989). Hidden agendas: The role of the learner in programme implementation In R. K. Johnson (Ed.), The Second Language Curriculum. Cambridge, Cambridge University Press. http://dx.doi.org/10.1017/cbo9781139524520.013

Reid, J. (1987). The learning style preferences of ESL students. TESOL Quarterly, 21, 87-103. http://dx.doi.org/10.2307/3586356

Richards, J. and C. Lockhart.(1994). Reflective Teaching in Second Language Classrooms. Cambridge University Press. http://dx.doi.org/10.1017/cbo9780511667169

Sternberg. Robert J. (1995) Styles of Thinking and Learning. Research for this article was supported under the Javits Act program by the office of Educational research and improvement of the USA Department of Education.(pp.265-292).

Stevick, E.W.(1976). Memory, meaning and method: Some psychological perspectives on language learning. Rowley, Mass.: Newbury House.

Willing, K.(1987). Learning Styles in Adult Migrant Education. Sydney: NSW Adult Migrant Education Service.

Yeh, Y., \& Wang, C. W. (2013). Effects of multimedia vocabulary annotations and learning styles on vocabulary learning. Calico Journal, 21(1), 131-144.

Zhang, Y. (2010). Cooperative language learning and foreign language learning and teaching. Journal of Language Teaching and Research, 1(1), 81-83. http://dx.doi.org/10.4304/j1tr.1.1.81-83 